\title{
Robert Jaruga*
}

\author{
SAMORZĄD MIEJSKI JAKO PODMIOT \\ STYMULUJĄCY WZROST GOSPODARCZY
}

\begin{abstract}
Streszczenie
Przedmiotem artykułu jest próba opisania roli władz miejskich w pobudzaniu wzrostu gospodarczego w skali lokalnej. Aktywność gospodarcza samorządu terytorialnego jest coraz bardziej znacząca, co wpływa na to, że staje się on kluczowym podmiotem gospodarowania. Wynika to nie tylko z przepisów prawa, ale także z coraz wyższych oczekiwań mieszkańców wspólnoty. Organy samorządu mają do dyspozycji różne instrumenty stymulowania rozwoju lokalnego. Szczególne miejsce zajmuje w nich administracja komunalna, która może być barierą, jak też czynnikiem lokalnego rozwoju gospodarczego.
\end{abstract}

Słowa kluczowe: samorząd terytorialny, wzrost gospodarczy, przedsiębiorczość lokalna

\section{Wprowadzenie}

Samorząd terytorialny odgrywa istotną rolę w państwie i systemie gospodarczym. Stanowi zdecentralizowaną formę sprawowania władzy publicznej oraz podejmuje decyzje o charakterze gospodarczym. Jako struktura społeczno-polityczna samorząd jest właścicielem wielkiego majątku trwałego, dysponuje znacznymi środkami finansowymi (budżet) oraz poprzez właściwe jednostki organizacyjne zarządza dużymi zasobami ludzkimi. Wymienione elementy to zasoby gospodarcze, dzięki którym możliwe staje się świadczenie dóbr i usług mieszkańców

* Robert Jaruga, doktorant, Uniwersytet Łódzki, Wydział Ekonomiczno-Socjologiczny, e-mail: robert@eko-vit.pl 
wspólnot samorządowych. Działalność samorządu w rozumieniu realizacji zadań własnych nosi charakter użyteczności publicznej. Zgodnie z Ustawą o samorządzie gminnym $^{1}$ i Ustawą o gospodarce komunalnej ${ }^{2}$, wszystkie zadania własne mają cechy użyteczności publicznej, a ich celem jest bieżące i nieprzerwane zaspokajanie zbiorowych potrzeb ludności poprzez świadczenie usług powszechnie dostępnych. Oznacza to, że gospodarka komunalna (samorządowa) obejmuje zadania własne poszczególnych jednostek samorządu terytorialnego.

Celem artykułu jest próba zarysowania roli i funkcji samorządu terytorialnego na poziomie podstawowym, tj. miasta, w podejmowaniu działalności gospodarczej, która nakierowana jest na rozwój (wzrost) lokalny. Obok wielu uczestników wspólnoty miejskiej jej organy (władze), tzn. rada miasta, prezydent lub burmistrz oraz związana z nimi administracja, zajmują w strukturze decyzyjnej miejsce szczególne. Rozważania w artykule mają charakter teoretyczny i koncentrują się bardziej na zarysowaniu problemu, niż na jego dogłębnej analizie. Do tej pory w literaturze przedmiotu podmiot prowadzący lokalną politykę rozwoju był traktowany agregatowo (najczęściej jako władze), podczas gdy składa się on z trzech elementów (subpodmiotów), tj. czynnika politycznego, organu wykonawczego oraz administracji. Oczywiście, najważniejszym podmiotem w samorządzie terytorialnym są jego mieszkańcy, którzy odgrywają rolę swoistego suwerena.

\section{Rola samorządu w przedsiębiorczości lokalnej}

Samorząd miasta realizuje zadania własne, prowadząc działalność gospodarczą, niezależnie od tego, czy jest obliczona na zysk, czy nie ${ }^{3}$. Działalność ta jest realizowana w oparciu o posiadane zasoby gospodarcze, które są wykorzystywane poprzez uruchomienie procesu zarządzania. Samorząd miasta z punktu widzenia ekonomicznego jest aktywny gospodarczo, bowiem prowadzi przedsiębiorczość komunalną. Zatem przez przedsiębiorczość lokalną rozumie się działalność realizowaną przez jednostki samorządu terytorialnego dla wykonywania

1 Ustawa z dnia 8 marca 1990r. o samorządzie gminnym, DzU z 2001 r., nr 142, poz. 1591 z późn. zm.

2 Ustawa z dnia 20 grudnia 1996r. o gospodarce komunalnej, DzU z 1997 r., nr 9, poz. 43 z późn. $\mathrm{zm}$.

3 W okresie międzywojennym w Polsce samorząd miejski prowadził dwa typy przedsiębiorczości: nastawioną na cele komercyjne (rzeźnie, tartaki, fabryki) i nieobliczoną na osiąganie zysku (przedsiębiorstwa użyteczności publicznej); zob. A. Ginsbert-Gebert, Polityka komunalna, PWE, Warszawa 1984, s. 37-38. 
zadań własnych, jak też działalność podmiotów prywatnych i społecznych, kierujących się swoimi celami i interesami. Według koncepcji tzw. nowej logiki rozwoju terytorialnego, władze miejskie stają się istotnym podmiotem ingerencji w mechanizmy rynkowe ${ }^{4}$.

Z istoty samorządu terytorialnego wynika konieczność świadczenia określonych usług publicznych w skali lokalnej, zaspokajających podstawowe, zbiorowe potrzeby mieszkańców. Usługi te mają charakter administracyjny, techniczny i społeczny ${ }^{5}$. Usługi administracyjne świadczy urząd zatrudniający urzędników. Pozostałe usługi komunalne świadczone są na podstawie urządzeń zaliczanych do tzw. infrastruktury technicznej (drogi, transport, media dostarczające wodę, energię, odprowadzające ścieki) i społecznej (placówki edukacyjne, zdrowotne, kulturalne). Usługi techniczne zaspokajają elementarne potrzeby ludzi, zaś społeczne - tzw. potrzeby wyższego rzędu (według klasyfikacji Maslowa) ${ }^{6}$.

Głównym celem funkcjonowania samorządu jest rozwój lokalny związany z odpowiednim zaspokajaniem potrzeb społecznych członków tego samorządu. Oznacza to konieczność spełniania wszelkich warunków wpływający (działających stymulująco) na przebieg procesów rozwojowych. Jednym nich jest sprawny proces świadczenia usług (oddziaływanie pośrednie). Jeśli miasto jest dobrze zorganizowane i wyposażone $\mathrm{w}$ niezbędne, nowoczesne urządzenia infrastrukturalne, to ich stan i funkcjonowanie wpływa dodatnio na ewentualne decyzje lokalizacyjne. Inwestor nie pokrywa wtedy kosztów związanych z uzbrojeniem terenu. Wygląd miasta i jego elementów oraz możliwość organizacji czasu wolnego może zachęcić lub zniechęcić inwestorów do lokowania swojej działalności na jego terenie.

Jednocześnie władze miasta prowadząc politykę, mogą w określonym stopniu wpływać na podniesienie aktywności gospodarczej, polegającej na wzroście liczby podmiotów gospodarczych, niezależnie od ich wielkości. Powszechny jest pogląd, że jedynie duży, zagraniczny inwestor jest w stanie uzdrowić sytuację gospodarczą w mieście, kierując ją na tory szybkiego wzrostu gospodarczego w mieście. Jak zauważa S. Korenik, wygodniejszym i szybszym sposobem wpływania na rozwój gospodarczy gminy jest lokalizacja dużej inwestycji. Należy

4 R. Brol, Rozwój lokalny - nowa logika rozwoju gospodarczego, w: Gospodarka lokalna $w$ teorii i praktyce, Prace Naukowe Akademii Ekonomicznej we Wrocławiu nr 785, Wrocław 1998, s. 11-15.

5 Por. K. Pakoński, Zintegrowane zarządzanie finansami zorientowane na cele, Municipium, Warszawa 2001, s. 16.

6 M. Kostera, Podstawy organizacji i zarzadzania, Wyższa Szkoła Przedsiębiorczości i Zarządzania im. Leona Koźmińskiego, Warszawa 1998, s. 43. 
jednak pamiętać, że więksi przedsiębiorcy często w warunkach kryzysowych przenoszą zyski na inne obszary. Natomiast mali przedsiębiorcy są integralnie związani z danym miejscem? ${ }^{7}$. Taki punkt widzenia wydaje się jednak zbyt wąski, bowiem z tego wynika, że każdy nowy inwestor jest pożądany. Zdaniem A. Zalewskiego, ,inwestorzy nie konkurują o lokalizację, lecz władze lokalne, regionalne konkurują o pozyskanie inwestorów"8.

\section{Istota rozwoju lokalnego}

Pojęcie „rozwój lokalny” nie jest jednolicie definiowane, a najczęściej w próbach opisu tego terminu eksponuje się cechę lokalności lub instytucje biorące w nim udział. Przez rozwój lokalny najogólniej należy rozumieć wszelkie pozytywne zmiany odczuwalne przez mieszkańców miasta (poprawa jakości życia) oraz przedsiębiorców (rozwój firmy i korzyści finansowe). Istotą rozwoju lokalnego są postępowe zmiany w trzech sferach: gospodarczej, społecznej i kulturowej, czemu towarzyszy wsparcie instytucji publicznych ${ }^{9}$. Rozwój lokalny jest procesem, który obejmuje zmiany o charakterze ilościowym i jakościowo-strukturalnym. Według J.J. Paryska, rozwój lokalny należy traktować bardzo szeroko, jako działania gospodarcze i społeczne, a nawet utożsamiać go z gospodarką lokalną ${ }^{10}$. R. Brol uważa, że rozwój lokalny to działanie społeczności lokalnej z udziałem innych podmiotów w celu poprawy i tworzenia walorów użytkowych obszaru, tworzenia warunków gospodarki lokalnej oraz zapewnienia ładu przestrzennego i ekologicznego. Jego rezultatem jest tworzenie nowych wartości ${ }^{11}$.

$\mathrm{Na}$ znaczenie zasad rozwoju zrównoważonego w rozwoju lokalnym zwraca uwagę T. Domański ${ }^{12}$. Nie jest to łatwy proces, ponieważ wymaga pogodzenia (zharmonizowania) trzech różnych logik: społecznej, gospodarczej

7 S. Korenik, Rola matej i średniej przedsiębiorczości w rozwoju lokalnym (rozwiązania funkcjonujace w Polsce), w: Gospodarka lokalna w teorii i praktyce, Prace Naukowe Akademii Ekonomicznej we Wrocławiu nr 860, Wrocław 2000, s. 181-182.

${ }^{8}$ A. Zalewski, Konkurencja między jednostkami terytorialnymi a efektywność gospodarki, w: Gospodarka lokalna w teorii i praktyce, Prace Naukowe Akademii Ekonomicznej we Wrocławiu nr 1124, Wrocław 2006, s. 259.

9 Samorząd terytorialny i rozwój lokalny, red. A. Piekara, Z. Niewiadomski, Uniwersytet Warszawski, Warszawa 1992, s. 17.

10 J.J. Parysek, Podstawy gospodarki lokalnej, Wydawnictwo Naukowe Uniwersytetu im. Adama Mickiewicza, Poznań 2001, s. 46-47

${ }_{11}$ R. Brol, Rozwój miasta, w: Ekonomika i zarzadzanie miastem, red. R. Brol, Wydawnictwo Akademii Ekonomicznej we Wrocławiu, Wrocław 2004, s. 201-202.

12 T. Domański, Strategiczne planowanie rozwoju gospodarczego gminy, Agencja Rozwoju Komunalnego, Warszawa 1999, s. 16. 
i ekologicznej ${ }^{13}$. A. Zalewski uważa zaś, że zrównoważony rozwój lokalny jest bardziej postulatem niż rzeczywistością.

Mając na uwadze cel artykułu, najbardziej adekwatną definicję rozwoju lokalnego w aspekcie ekonomicznym podaje E.J. Blakely, twierdząc, iż lokalny rozwój gospodarczy jest procesem, który ma na celu tworzenie nowych miejsc pracy i ożywienie działalności gospodarczej ${ }^{14}$. Z kolei A. Klasik za treść lokalnego rozwoju gospodarczego uważa także nowe firmy i nowe miejsca pracy ${ }^{15}$. Większość autorów traktuje rozwój lokalny jako proces tworzenia nowych wartości, w tym intelektualnych, opartych na wiedzy. Rozwój lokalny w wymiarze ekonomicznym stanowi podstawowy cel polityki realizowanej przez władze samorządowe w mieście. Wynika z tego ważna konkluzja. Miejsca pracy tworzą przede wszystkim przedsiębiorcy, inwestorzy, dlatego to oni powinni być przedmiotem szczególnego zainteresowania władz miejskich. W pewnym sensie również samorząd terytorialny oferuje zatrudnienie w służbach komunalnych (jednostki, zakłady budżetowe, spółki miejskie). W małych miastach samorządowe urzędy oraz jednostki organizacyjne są znaczącym i atrakcyjnym miejscem pracy na lokalnym rynku. Według J.T. Hryniewicza, misją gospodarczą samorządu terytorialnego jest troska o jakość życia mieszkańców poprzez „dostarczanie usług publicznych i dbałość o rozwój gospodarczy"16.

\section{Instrumenty polityki lokalnego rozwoju.}

Cele rozwoju lokalnego są niejako narzucone samorządowi terytorialnemu z zewnątrz, stanowią swoistą „datę" ekonomiczną. Są one oczywiste, ponieważ wiążą się z różnymi aspektami rozwoju lokalnego. Problem polega na wyborze odpowiednich (zakreślonych prawem) narzędzi (metod, technik, rozwiązań, zapisów ustawowych) zorientowanych na cele rozwojowe. W literaturze specjalistycznej

13 A. Zalewski, Czy zrównoważony rozwój lokalny jest możliwy?, w: Gospodarka lokalna w teorii i praktyce, Prace Naukowe Akademii Ekonomicznej we Wrocławiu nr 3 (1203), Wrocław 2008, s. 312.

14 E.J. Blakely, Planning Local Economic Development. Theory and Practice, SAGE Library of Social Research, 1989, London, za: D. Morisson, Rozwój gospodarczy. Strategiczne podejście do zarządzania gmina, USAID, Agencja Rozwoju Komunalnego, Warszawa 1997, s. 1.

15 A. Klasik, Zarzadzanie rozwojem lokalnym, w: Zarzadzanie rozwojem gminy $w$ zespołach miejsko-przemysłowych, red. F. Kuźnik, PTE, Katowice 1996, s. 16.

16 J.T. Hryniewicz, Administracja samorządowa-misje, własność i kontekst organizacyjny, „Samorząd Terytorialny” 2004, nr 10, s. 34. 
stosuje się różne klasyfikacje tego typu instrumentów. Według popularnego podziału są to instrumenty bezpośredniego i pośredniego oddziaływania ${ }^{17}$.

Dla celów niniejszego opracowania przyjęto klasyfikację narzędzi zaproponowaną przez E. Wojciechowskiego, który podzielił narzędzia zarządzania na: zorientowane na rozwój, organizacyjne, ekonomiczno-finansowe, marketingowe, nastawione na jakość, infrastrukturalne, przekształceniowe, informacyjne, efektywnościowe oraz analityczne ${ }^{18}$. Instrumenty ukierunkowane na rozwój, organizacyjne, ekonomiczno-finansowe oraz infrastrukturalne mają szczególny charakter dla przedsiębiorców w mieście. Z kolei dokumentacja planistyczna (a zwłaszcza plany przestrzennego zagospodarowania) określa obszar miasta $\mathrm{z}$ rozmieszczeniem funkcji jego zagospodarowania. Funkcje te wraz z kształtowaniem pozytywnego wizerunku są bardzo istotne, jeśli chodzi o przyciąganie potencjalnych przedsiębiorców. Rozwiązania organizacyjne, jakość obsługi interesanta oraz funkcje informacyjne urzędu mieszczą się w obszarze działań administracji komunalnej.

Jak wynika z badań przeprowadzonych pod kierunkiem P. Swianiewicza, najistotniejszy wpływ na lokalny rozwój gospodarczy mają takie kategorie zmiennych, jak kapitał ludzki (wykształcenie), społeczeństwo obywatelskie oraz infrastruktura. Mniejsze znaczenie mają instytucje wspierania biznesu, przywództwo, współpraca oraz marketing (promocja). Badanie potwierdziło marginalne znaczenie działań skupionych na obniżaniu kosztów prowadzenia działalności gospodarczej przez lokalne przedsiębiorstwa ${ }^{19}$.

\section{Administracja jako bariera rozwoju przedsiębiorczości}

Paradoksalnie czynniki rozwoju lokalnego mogą wpływać na ograniczenie tego rozwoju - mogą być jego barierą. Ważne miejsce zajmuje w nich jakość administracji samorządowej, która ma w tym przypadku charakter wewnętrzny, związany z układem organizacyjno-instytucjonalnym, stanowiącym podstawę podmiotów polityki rozwoju lokalnego. Administracja samorządowa obsługuje organ stanowiący miasta (radę miasta), pracuje dla organu wykonawczego

17 L. Patrzałek, Narzędzia oddziaływania samorzadów terytorialnych na rozwój lokalny i regionalny, „Samorząd Terytorialny” 1996, nr 5, s. 43-45.

18 E. Wojciechowski, Gospodarka samorzadu terytorialnego, Difin, Warszawa 2012, s. $95-105$.

19 P. Swianiewicz, J. Łukomska, Władze samorzadowe wobec lokalnego rozwoju gospodarczego. Które polityki sq skuteczne?, „Samorząd Terytorialny” 2004, nr 6, s. $26-27$. 
(prezydenta miasta). Sama w sobie zawiera cechy władzy publicznej, ponieważ podejmuje decyzje administracyjne w żywotnych dla mieszkańców sprawach. Urząd miasta jest fachowym aparatem urzędniczym, realizując zadania własne miasta. Jego wielkość rośnie wraz ze wzrostem skali miasta ${ }^{20}$. Organizacja urzędu, procedury, styl działania może być zarówno czynnikiem sprzyjającym dla interesanta i jego obsługi, jak też elementem utrudniającym załatwienie sprawy przez mieszkańca czy inwestora, zniechęcającym ich.

Badania na temat uwarunkowań swobody gospodarczej dość jednoznacznie wskazują na aparat administracyjny jako doniosły czynnik ograniczający rozwój przedsiębiorczości. Wydaje się, że barierę tę można w niezbyt długim czasie dość łatwo usunąć. Rzecz sprowadza się do wydatnej poprawy jakości administracji połączonej z innym nastawieniem na potencjalnego interesanta, w naszym przypadku - przedsiębiorcy.

$\mathrm{Z}$ badań międzynarodowych wyłania się istotne znaczenie administracji publicznej jako elementu otoczenia dla przedsiębiorców prowadzących działalność gospodarczą. Ciekawe informacje przynosi ranking Doing Bussines czy indeksy The Europe 2020 Competitiveness Report. W tym ostatnim zestawieniu prezentującym konkurencyjność krajów Polska w 2012 roku znalazła się na 23. miejscu spośród 27 krajów Unii Europejskiej ${ }^{21}$.

\section{Podsumowanie}

Z przedstawionych rozważań wynika istotna pozycja samorządu terytorialnego w systemie ekonomicznym państwa. Samorząd terytorialny staje się jako całość swoistym podmiotem w sensie gospodarowania. Konkretyzacja tzw. władz lokalnych (miejskich) polega na wyodrębnieniu rady miejskiej, prezydenta miasta oraz administracji miasta jako głównych podmiotów lokalnej polityki rozwoju, funkcjonujących zgodnie ze swoją pozycją i kompetencjami. W kontekście nowoczesnego zarządzania miastem od podmiotów tych oczekuje się dbałości o dobro publiczne, elastyczności, innowacyjności, gospodarności, skuteczności i życzliwego podejścia do mieszkańca, który jest nie tylko konsumentem usług, ale też podatnikiem, wyborcą i interesantem urzędu. Mieszkaniec odgrywa zatem wiele

20 M. Wojciechowski, Koszt władzy w polskim samorzadzie terytorialny, Difin, Warszawa 2014, s. 105-107.

21 A. Raszkowski, Ranking krajów UE na przykładzie The Europe 2020 Competitiveness Report, w: Gospodarka regionalna w teorii i praktyce, red. D. Strahl, A. Raszkowski, D. Głuszczuk, Prace Naukowe Uniwersytetu Ekonomicznego we Wrocławiu nr 333, Wrocław 2014, s. 109. 
ról, a zaspokojenie jego potrzeb powinno być rozstrzygające przy ocenie działań poszczególnych organów władzy miejskiej.

Realizacji rozwoju lokalnego (miasta) służy polityka władz miejskich i związany $z$ nią proces zarządzania. $Z$ przedstawionych wywodów wyłania się dość czytelny obraz możliwości oddziaływania organów miasta na stymulowanie działań rozwojowych. Organy te najsilniej mogą wpływać poprzez oddziaływanie pośrednie, tj. budowę atrakcyjnych warunków o różnym natężeniu oraz wysoki standard bezpośredniej obsługi inwestora, zarówno rodzimego, jak i zewnętrznego. Wydaje się, że możliwości zastosowania bezpośrednich instrumentów finansowych stają się coraz bardziej ograniczone, gdyż zagrażają wprost kondycji finansowej miasta. Ilustracją może być obniżenie podatku od nieruchomości, co będzie skutkować zmniejszeniem nadwyżki operacyjnej, determinującej wydatki inwestycyjne (a zatem i rozwój). Ogólnie mówiąc, oddziaływanie władz lokalnych na rozwój gospodarczy odbywa się poprzez kształtowanie warunków prowadzenia działalności gospodarczej.

Niezależnie od tego swoistym „oczkiem w głowie” powinny być nie tylko duże podmioty, lecz lokalny kapitał, dysponujący niewielkim potencjałem produkcyjnym i usługowym. To on tworzy tkankę wyznaczaną w zarysie przez zagraniczne koncerny. Władze miejskie występują wobec tego w podwójnej roli: gwaranta dostarczenia usług publicznych (provide) i kreatora rozwoju lokalnego na miarę swoich potrzeb i możliwości.

\section{Literatura}

Brol R., Rozwój miasta, w: Ekonomika i zarzadzanie miastem, red. R. Brol, Wydawnictwo Akademii Ekonomicznej we Wrocławiu, Wrocław 2004.

Brol R., Rozwój lokalny - nowa logika rozwoju gospodarczego, w: Gospodarka lokalna w teorii i praktyce, Prace Naukowe Akademii Ekonomicznej we Wrocławiu nr 785, Wrocław 1998.

Domański T., Strategiczne planowanie rozwoju gospodarczego gminy, Agencja Rozwoju Komunalnego, Warszawa 1999.

Ginsbert-Gebert A., Polityka komunalna, PWE, Warszawa 1984.

Hryniewicz J.T., Administracja samorzadowa-misje, własność i kontekst organizacyjny, „Samorząd Terytorialny” 2004, nr 10.

Klasik A., Zarzadzanie rozwojem lokalnym, w: Zarzadzanie rozwojem gminy w zespotach miejsko - przemystowych, red. F. Kuźnik, PTE, Katowice 1996. 
Korenik S., Rola małej i średniej przedsiębiorczości $w$ rozwoju lokalnym (rozwiazania funkcjonujace $w$ Polsce), w: Gospodarka lokalna $w$ teorii i praktyce, Prace Naukowe Akademii Ekonomicznej we Wrocławiu nr 860, Wrocław 2000.

Kostera M., Podstawy organizacji i zarządzania, Wyższa Szkoła Przedsiębiorczości i Zarządzania im. Leona Koźmińskiego, Warszawa 1998.

Morisson D., Rozwój gospodarczy. Strategiczne podejście do zarządzania gmina, USAID, Agencja Rozwoju Komunalnego, Warszawa 1997.

Pakoński K., Zintegrowane zarządzanie finansami zorientowane na cele, Municipium, Warszawa 2001.

Parysek J.J., Podstawy gospodarki lokalnej, Wydawnictwo Naukowe Uniwersytetu im. Adama Mickiewicza, Poznań 2001.

Patrzałek L., Narzędzia oddziaływania samorząów terytorialnych na rozwój lokalny i regionalny, „Samorząd Terytorialny” 1996, nr 5.

Raszkowski A., Ranking krajów UE na przykładzie The Europe 2020 Competitiveness Report, w: Gospodarka regionalna w teorii i praktyce, red. D. Strahl, A. Raszkowski, D. Głuszczuk, Prace Naukowe Uniwersytetu Ekonomicznego we Wrocławiu nr 333, Wrocław 2014.

Samorzad terytorialny i rozwój lokalny, red. A. Piekara, Z. Niewiadomski, Uniwersytet Warszawski, Warszawa 1992.

Swianiewicz P., Łukomska J., Władze samorzadowe wobec lokalnego rozwoju gospodarczego. Które polityki są skuteczne?, „Samorząd Terytorialny” 2004, nr 6.

Ustawa z dnia 20 grudnia 1996 r. o gospodarce komunalnej, DzU z 1997 r., nr 9, poz. 43 z późn. zm.

Ustawa z dnia 8 marca 1990 r. o samorządzie gminnym, DzU z 2001 r., nr 142, poz. 1591 z późn. zm.

Wojciechowski E., Gospodarka samorzadu terytorialnego, Difin, Warszawa 2012.

Wojciechowski M., Koszt władzy w polskim samorządzie terytorialny, Difin, Warszawa 2014.

Zalewski A., Czy zrównoważony rozwój lokalny jest możliwy?, w: Gospodarka lokalna w teorii i praktyce, Prace Naukowe Akademii Ekonomicznej we Wrocławiu nr 3 (1203), Wrocław 2008.

Zalewski A., Konkurencja między jednostkami terytorialnymi a efektywność gospodarki, w: Gospodarka lokalna $w$ teorii $i$ praktyce, Prace Naukowe Akademii Ekonomicznej we Wrocławiu nr 1124, Wrocław 2006. 
THE MUNICIPAL GOVERNMENT AS THE SUBJECT STIMULATING THE GROWTH IN THE ECONOMY

\begin{abstract}
Summary
An attempt to outline the role of city authorities in stimulating the growth in the economy in the local scale is a subject of the article. The local self-government is acting more and more greater role in the economic activity, becoming a crucial entity of the management. It results not only from provisions of the law but more and more high expectations of residents of community. Self-government bodies have various instruments of stimulating the local development at their disposal. In them a council administration department which can be a barrier, as well as a factor of the local economic development is taking the special place.
\end{abstract}

Keywords: regional government, local entrepreneurship, economic development

Translated by Robert Jaruga 